\title{
First report of the occurrence of Ophiocordyceps melolonthae (Ascomycota: Hypocreales: Ophiocordycipitaceae) in larvae of Diloboderus abderus Sturm (Coleoptera: Melolonthidae) in Brazil
}

\author{
Geraldo Salgado-Neto ${ }^{1,3}$, Ivair Valmorbida ${ }^{2}$, Jerson Vanderlei Carús Guedes ${ }^{1}$ \& Elena Blume ${ }^{I}$ \\ ${ }^{1}$ Universidade Federal de Santa Maria, Centro de Ciências Rurais, Departamento de Defesa Fitossanitária, \\ Campus Universitário, Santa Maria, RS, Brazil. \\ ${ }^{2}$ Universidade Federal de Santa Maria, Departamento de Defesa Fitossanitária, Graduação em Agronomia, \\ Campus Universitário, Santa Maria, RS, Brazil. \\ ${ }^{3}$ Corresponding author: Geraldo Salgado-Neto,e-mail: gsalgado@bol.com.br
}

\begin{abstract}
SALGADO-NETO, G., VALMORBIDA, I., GUEDES, J.V.C., BLUME, E. First report of the occurrence of Ophiocordyceps melolonthae (Ascomycota: Hypocreales: Ophiocordycipitaceae) in larvae of Diloboderus abderus Sturm (Coleoptera: Melolonthidae) in Brazil. Biota Neotropica. 15(2): e20140108. http://dx.doi.org/10.1590/1676-06032015010814
\end{abstract}

\begin{abstract}
This note is the first report on the infection of Diloboderus abderus Sturm (Coleoptera: Melolonthidae) larvae by the fungus Ophiocordyceps melolonthae (Hypocreales: Ophiocordycipitaceae) in subtropical Brazil. Identification was made possible by extraction and sequencing of the fungal DNA that was covering the larvae's mouthparts, prothorax, cuticle, and digestive tract (alimentary canal). Amplification, sequencing and comparison of the ITS region of the ribosomal DNA with voucher sequences of GenBank were performed and were 95\% similar to Ophiocordyceps melolonthae. The fungus is an entomopathogen which attacks Melolonthidae larvae, having scientific and economic importance because of the need for increased knowledge on its distribution and on alternatives for biological control of white grubs.
\end{abstract}

Keywords: Biological control, dissemination, entomopathogen, entomopathogenic fungi, natural infection.

SAlGADO-NETO, G., VALMORBIDA, I., GUEDES, J.V.C., BLUME, E. Primeiro registro da ocorrência de Ophiocordyceps melolonthae (Ascomycota: Hypocreales: Ophiocordycipitaceae) em larvas de Diloboderus abderus Sturm (Coleoptera: Melolonthidae) no Brasil. Biota Neotropica. 15(2): e20140108. http://dx.doi.org/10.1590/1676-06032015010814

\begin{abstract}
Resumo: Esta nota é o primeiro registro da infecção de larvas de Diloboderus abderus Sturm pelo fungo Ophiocordyceps melolonthae na região subtropical do Brasil. A identificação foi possível graças à extração e sequenciamento do DNA do fungo que cobria o aparelho bucal, protórax, cutícula e aparelho digestivo (canal alimentar) das larvas. Amplificação, sequenciamento e comparação da região ITS com sequências voucher do GenBank foram realizados, mostrando 95\% de similaridade com Ophiocordyceps melolonthae. O fungo é um entomopatógeno que ataca larvas Melolonthidae, tendo importância científica e econômica devido à necessidade de aumento do conhecimento sobre sua distribuição e de alternativas de controle biológico de corós.

Palavras-chave: Controle biológico, disseminação, entomopatógeno, fungos entomopatogênicos, infecção natural.
\end{abstract}

Entomopathogenic fungi have broad host range (DeFaria \& Wraight 2007), geographical range and potential to control white grubs. For these reasons, it is important to collect, purify and conserve germplasm of the wide variety of species as they may be used in a selection of strains to perform a biological control program. The conservation of strains in reference collections should be priority for some genotypes that may be lost due to local environmental changes (Hernandez-Velazquez et al. 2011).

In Brazil, previous records have shown that natural epizooties caused by the fungus Cordyceps unilateralis (Euascomycetes: Hypocreales) were found in adults of the ants Camponotus sp. and Atta cephalotes (Hymenoptera:
Formicidae) in the Amazon Forest (Andrade 1980). Recently, in Minas Gerais, Ophiocordyceps unilateralis (Hypocreales: Clavicipitaceae) was discovered as a specific fungal pathogen of the ant species Camponotus rufipes, C. balzani, $C$. melanoticus and C. novogranadensis (Formicidae: Camponotini) (Evans et al. 2011). Moreover, epizooties caused by fungi in the "Planalto Region" of the state of Rio Grande do Sul have been the main cause of white grubs collapse in wheat. The fungi Metarhizium anisopliae (Metchnikoff) Sorokin, Beauveria bassiana (Bálsamo) Vuillemin and Cordyceps sp. are the most common fungi found infecting Melolonthidae larvae (Gassen 1992, Salvadori 2000, Salvadori \& Pereira 2006). 


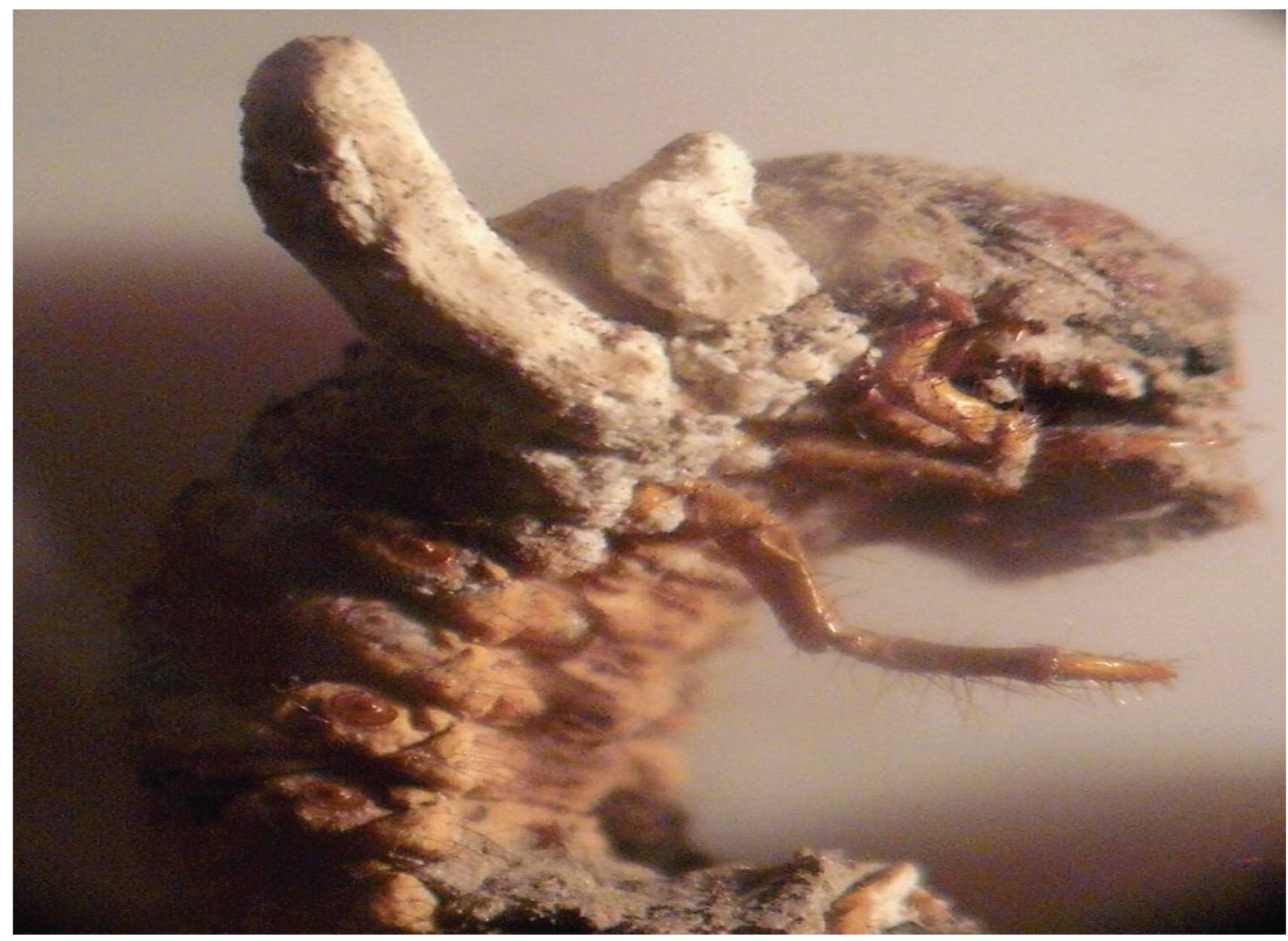

Figure 1. Ophiocordyceps melolonthae infecting Diloboderus abderus larva. Foto: Salgado-Neto, 2014.

The Cordyceps genus was established as an ascomycete, fungal pathogen of arthropods bearing the ascospore producing structures on stromata arising from the host cadaver. Cordyceps unilateralis, originally characterizing species with non-fragmenting ascospores, was reorganized in the genus Ophiocordyceps (Hypocreales: Ophiocordycipitacae), which currently comprises around 160 species (Sung et al. 2007, Evans et al. 2011). These parasites infect many different insects with a wide ecological range. The orders infected are Coleoptera, Blattaria, Dermaptera, Diptera, Hymenoptera, Hemiptera, Isoptera, Lepidoptera, Mantodea, Orthoptera and Odonata (Evans et al. 2011, Araújo \& Hughes, 2014).

Here, we report the infection of Ophiocordyceps melolonthae in the third instar larvae of the white grub Diloboderus abderus in subtropical Brazil. Beside increasing the information about its geographical distribution, our finding is also important to biological control due to the increase of white grubs occurrence in cultivate and uncultivated fields in Brazil.

Trenches $(50 \mathrm{~cm}$ long x $25 \mathrm{~cm}$ wide x $30 \mathrm{~cm}$ deep) were opened in a native grassland and 35 samples spaced $64 \mathrm{~m}$ apart were taken in approximately 15 hectares, at the district of Umbú, Rosário do Sul - Rio Grande do Sul, Brazil $\left(30^{\circ} 35^{\prime} \mathrm{S}\right.$ and $54^{\circ} 46^{\prime} \mathrm{W}$ ). Both in 2011 and 2012, larvae of D. abderus with soil were collected individually in $60 \mathrm{~mL}$ plastic containers and transported to the Laboratory of Integrated Pest Management of Universidade Federal de Santa Maria (UFSM) to confirm the white grub species. The larvae presented a whitish cover and a horn like structure attached to it (Figures 1 and 2). In the Laboratory of Phytopathology of UFSM the larvae were superficially disinfected and rinsed in sterile distilled water.
Subsequently, some were frozen and others were dissected and separated into the following parts: mouthparts, prothorax, cuticle, and digestive tract (alimentary canal), which were then placed in Eppendorf tubes containing $100 \mathrm{~mL}$ of $0.85 \%$ saline solution.

Afterwards, the parts were added to Petri dishes with PDA (Potato Dextrose Agar) media and incubated in a growth chamber with a temperature of $25.6{ }^{\circ} \mathrm{C}$ and a photoperiod of $12 \mathrm{~h}$ for seven days. Since there was no growth on PDA, frozen specimens with the whitish structure resembling a stroma of Ophiocordyceps spp. (Evans et al. 1999) were sent to the Biological Institut of São Paulo for molecular identification.

Extraction of the isolated DNA was performed according to the method employing the reagent C.T.A.B. (cetyltrimethylammonium bromide) described by Doyle \& Doyle (1987). The stroma was triturated in micro tubes with the aid of a plastic pistil and the extracted genomic DNA was subjected to polymerase chain reaction (PCR) for amplification of the ITS region (Internal Transcribed Spacer) located between the genes encoding the $18 \mathrm{~S}$ and $28 \mathrm{~S}$ ribosomal RNAs. The primers for the ITS region were ITS1 (5'-TCCGTAGGTGAACCTGCGG-3') and ITS4 (5'-TCCTCCGCTTATTGATATGC- $3^{\prime}$ ) (White et al. 1990). The amplified products were purified by precipitation with polyethylene glycol (Schmitz \& Riesner 2006), subjected to sequencing by the chain termination reaction method employing the reagent Big Dye 3.1 (Applied Biosystems) and analyzed by automated capillary sequencer 3500 L (Applied Biosystems). The sequence obtained was deposited (GenBank access code KR082313) and compared to voucher sequences present in the GenBank of the 


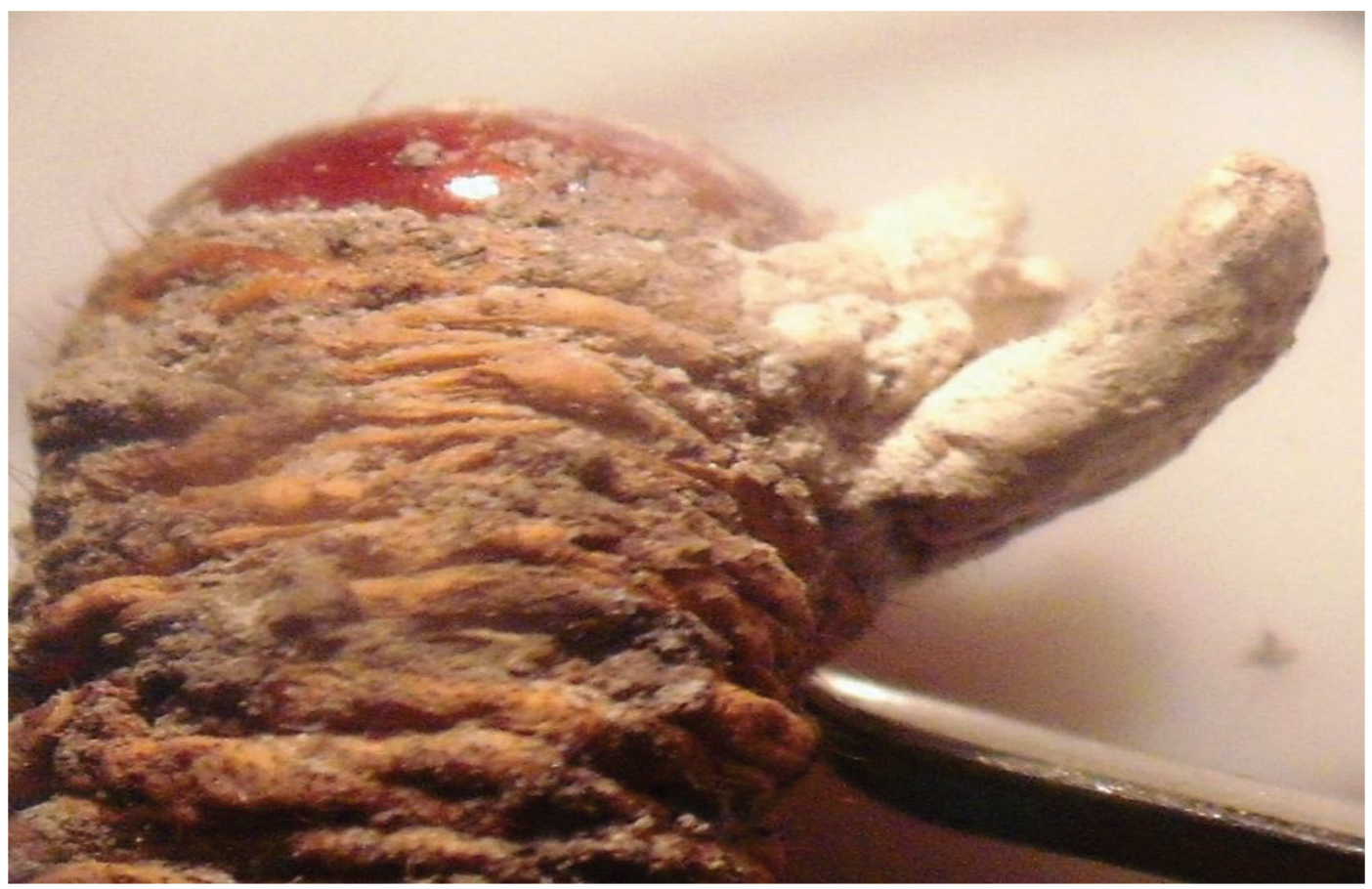

Figure 2. Ophiocordyceps melolonthae infecting Diloboderus abderus larva.

Foto: Salgado-Neto, 2014.

National Center for Biotechnology Information (NCBI) (http://www.ncbi.nlm.nih.gov), using the Blastn program (Altschul et al. 1990). The ITS sequenced is the following: AACCGCGGCGCCCGCCGGAGGACCCCACGACTCTCTTCCGCCCCAGCGGCATCTTCCGGGTGAGCCATCACGAATGAGTCAAAACTTTCAACAACGGATCTCTTGGTTCTGGCATCGATGAAGAACGCAGCGAAATGCGATAAGTAATGTGAATTGCAGAATTCAGTGAATCATCGAATCTTTGAACGCACATTGCGCCCGCCAGCACTCTGGCGGGCATGCCTGTCCGAGCGTCATTTCAGCCCTCGAGCCCCCCCCGGGGCTCGGCGTTGGGGCCCGGCCCGCCGCGGCCGCCCCCCAAATCCAGTGGCGACCCCGCCGCGGCCTCCCCTGCGCAGTAGCACACGCCTCGCACCGGAGCCCCGGCGGCGGTCCTCGCCGTGAAACGCGACCAGCCTCCCAGGAGAGTTGACCTCGGATCAGGTAGGGGTACCCGCTGAACTTAAGCATATCAATAAGCGGAGGAA. The fungus was identifies as Ophiocordyceps melolonthae (Spatafora et al. 2007), being the probable cause of larval death.

The species Ophiocordyceps melolonthae (= Cordyceps melolonthae) were studied in the United States of America (Mains 1958) and Mexico (Pérez-Silva 1977, Guzmán et al. 2001). Evans et al. (1999) showed the fungus being parasitic to Cochliotus melolonthoides (Gerst.), a Scarabaeidae from Tanzania, and on a melolonthid larva buried in Amazonian Ecuador forest soil that agrees well with the specimens studied here. Lloyd (1920) described subspecies of C. melolonthae from Brazil as "growing from the head of some larva" with subcylindric or globose stromata, about $20 \mathrm{~mm}$ long. From the macromorphology of stromata present in 10 collected larvae it was determined that the specimens collected represented a species of $C$. melolonthae. This fungus is considerad one of the strongest pathogen to scarabaeid insects, and there have been many attempts to use it as an agent for biological control of Melolonthidae larvae (Mains 1958, Ferron 1981, Sung et al. 2007).
Morphological investigations are necessary to characterize these teleomorphs and to determine whether they are synonyms as previously described Cordyceps species, such as C. staphylinidicola (Kobayasi \& Shimizu 1982), C. sulfurea (Kobayasi \& Shimizu 1983) and C. scarabaeicola (Kobayasi \& Shimizu 1976). Progress in methods for in vitro fruiting of Cordyceps species with Beauveria anamorphs are promising for developmental studies of Beauveria and its Cordyceps teleomorphs through integrated phylogenetics, developmental and mating studies (Sung et al. 2006, Lee et al. 2010, Rehner et al. 2011).

The natural occurrence in Melolonthidae larvae suggests that this fungus may play an important role in the control of white grubs and it must encourage more extensive studies on the possibility of utilizing this fungus in biological control programs.

\section{Acknowledgments}

We thank Dr. Sthephen A. Rehner, Systematic Mycology and Microbiology Laboratory/USDA-ARS, Dr. Ludwig H. Pfenning, Departamento de Fitopatologia/UFLA and Dr. Ricardo Harakava (Instituto Biológico de São Paulo), Laboratório de Bioquímica Fitopatológica, for their assistance in fungi identification.

\section{References}

ANDRADE, C.F.S. 1980. Epizootia natural causada por Cordyceps unilateralis (Hypocreales, Euascomycetes) em adultos de Camponotus sp. (Hymenoptera, Formicidae) na região de Manaus, Amazonas, Brasil. Acta Amazonica. 10(3): 671-677, http://www2. ib.unicamp.br/profs/eco_aplicada/arquivos/pesquisas/11_1_2.pdf.

ALTSCHUL, S.F., GISH, W., MILLER, W., MYERS, E.W. \& LIPMAN, D.J. 1990. Basic local alignment search tool. Journal 
Molecular Biology. 215: 403-410, http://www.cmu.edu/bio/education/courses/03510/LectureNotes/Altschul1990.pdf.

ARAÚJO, J.P.M. \& HUGHES, D.P. 2014. Diversity of entomopathogen fungi: Which groups conquered the insect body? bioRxiv doi: $10.1101 / 003756$

DEFARIA, M.R. \& WRAIGTH, S.P. 2007. Mycoinseticides and micoacaricides: a comprehensive list with worldwide coverage and international classification of formulation types. Biological Control. 43: 237-256, http://naldc.nal.usda.gov/download/11204/PDF.

DOYLE, J.J. \& DOYLE, J.L. 1987. A rapid DNA isolation procedure for small quantities of fresh leaf tissue. Phytochemical Bulletin. 19(1): 11-15, http://ci.nii.ac.jp/naid/10021087108/.

EVANS, H.C., SMITH, S.M., KATANDU, J.M. \& KAPAMA, J.T. 1999. A Cordyceps pathogen of sugar-cane white grubs in Tanzania. Mycologist. 13: 11-14, http://www.sciencedirect.com/science/ article/pii/S0269915X99800664.

EVANS, H.C., ELlIOT, S.L. \& HUGHES, D.P. 2011. Hidden Diversity Behind the Zombie-Ant Fungus Ophiocordyceps unilateralis: Four New Species Described from Carpenter Ants in Minas Gerais, Brazil. Plos One. 6(3): 17024. doi:10.1371/journal. pone. 0017024

FERRON, P. 1981. Pest Control by the fungi Beauveria and Metarhizium. In Microbial Control of Pests and Plant Diseases 1970-1980 (Burgues, H.D., ed.). Academic Press, London, p. 465-498.

GASSEN, D.N. 1992. Inimigos naturais de Diloboderus abderus no sul do Brasil. In Reunião sobre pragas subterrâneas dos países do cone sul. Anais: Embrapa-CNPMS. Sete Lagoas, n. 2. p. 168.

GUZMÁN, G., MORÓN, M.A., RAMÍREZ-GUILLÉN, F. \& WOLF, J.H.D. 2001. Entomopatogenous Cordyceps and related genera from Mexico with discussions on their hosts and new records. Mycotaxon. 78: 115-125, http://www.mycotaxon.com/vol/ abstracts/78/78.115.html.

HERNÁNDEZ-VELÁZQUEZ, M., ESPÍNDOLA, Z.C., VILLALOBOS, F.J., GARCÍA, L.L. \& CHORA, G.P. 2011. Aislamiento de hongos entomopatógenos en suelo y sobre gallinas ciegas (Coleoptera: Melolonthidae) en agroecosistemas de maíz. Acta Zoológica Mexicana. 27(3): 591-599, http://www1.inecol.edu.mx/ azm/AZM27\%283\%29-2011/07.-\%20Hernandez-Velazquez.pdf.

KOBAYASI, Y. \& SHIMIZU, D. 1976. The genus Cordyceps and its allies from New Guinea. Bulletin of the National Science Museum, Series B. 2: 133-151.

KOBAYASI, Y. \& SHIMIZU, D. 1982. Cordyceps species from Japan 4. Bulletin of the National Science Museum, Series B. 83: 79-91.

KOBAYASI, Y. \& SHIMIZU, D. 1983. Cordyceps species from Japan 6. Bulletin of the National Science Museum, Series B. 9: 1-21.

LEE, J.O., SUNG, G.H., HAN, S.K., KIM, T.W. \& SUNG, J.M. 2010. Cultural characteristics and fruiting body production in
Cordyceps bassiana. Mycobiology. 38: 118-121, http://www.ncbi. nlm.nih.gov/pmc/articles/PMC3741561/.

LLOYD, C.G. 1920. Mycological Notes 62. Mycological Writings. 6: 904-944.

MAINS, E.B. 1958. North American entomogenus species of Cordyceps. Mycologia. 50: 169-222.

PÉREZ-SILVA, E. 1977. Algumas espécies del gênero Cordyceps (Pyrenomycetes) em México. Boletín de la Sociedad Mexicana de Micología. 11: 145-153, http://www.scielo.org.mx/scielo.php?script $=$ sci_nlinks\&ref $=3658003 \&$ pid $=$ S18703453201200010000100039\& $\operatorname{lng}=$ es.

REHNER, S.A., MINNIS, A.M., SUNG, G., LUANGSA-ARD, J.J., DEVOTTO, L. \& HUMBER, R.A. 2011. Phylogeny and systematic of the anamorphic, entomopathogenic genus Beauveria. Mycologia. 102(5): 1055-1073, http://www.ncbi.nlm.nih.gov/pubmed/ 21482632.

SALVADORI, J.R. 2000. Coró-do-trigo. Passo Fundo: Embrapa Trigo, 56 p. (Embrapa Trigo. Documentos, 17).

SALVADORI, J.R. \& PEREIRA, P.R.V.S., 2006. Manejo integrado de corós em trigo e culturas associadas. Passo Fundo: Embrapa Trigo, 2006. 12p. (Comunicado Técnico 203). Available at: http://www. cnpt.embrapa.br/biblio/co/p_co203.pdf (accessed 1 December 2009).

SCHMITZ, A. \& RIESNER, D. 2006. Purification of nucleic acids by selective precipitation with polyethylene glycol 6000. Analytical Biochemistry. 354: 311-313, http://dx.doi.org/10.1016/j.ab.2006. 03.014.

SPATAFORA, J.W., SUNG, G.H., SUNG, J.M., HYWEL-JONES, N.L. \& WHITE, J.F. JR. 2007. Phylogenetic evidence for an animal pathogen origin of ergot and the grass endophytes. Molecular Ecology. 16(8): 1701-1711. http://dx.doi.org/10.1111/j.1365-294X. 2007.03225.x.

SUNG, G.H., HYWEL-JONES, N.L., SUNG, J.M., LUANGSAARD, J.J., SHRESTHA, B. \& SPATAFORA, J.W. 2007. Phylogenetic classification of Cordyceps and the clavicipitaceous fungi. Studies in Mycology. 57(1)(1): 5-59, http://www.ncbi.nlm.nih.gov/ pubmed/18490993 http://dx.doi.org/10.3114/sim.2007.57.01

SUNG, J.M., LEE, J.O., HUMBER, R.A., SUNG, G.H. \& SHRESTHA, B. 2006. Cordyceps bassiana and production of stromata in Cordyceps bassiana and production of stromata in vitro showing Beauveria anamorph in Korea. Mycobiology. 34: 1-6, http://www. ncbi.nlm.nih.gov/pubmed/24039462 http://dx.doi.org/10.4489/MYCO. 2006.34.1.001.

WHITE, T.J., BRUNS, T., LEE, S. \& TAYLOR, J.W. 1990. Amplification and direct sequencing of fungal ribosomal RNA genes for phylogenetics. In PCR Protocols: A Guide to Methods and Applications (Innis, M.A., Gelfand, D.H., Snisky, J.J. \& White, T.J.) Academic Press, Inc., New York, p.315-322. 